\title{
Analisis Resistensi Antibiotik Pada Bakteri Yang Berasosiasi Dengan Lalat (Musca domestica)
}

\author{
Oktira Roka Aji ${ }^{1)}$ \\ ${ }^{1}$ Program Studi Biologi, Fakultas Sains dan Teknologi Terapan, Universitas Ahmad Dahlan \\ Email: oktira.aji@bio.uad.ac.id
}

APA Citation: Aji, O. R. (2020). Analisis Resistensi Antibiotik Pada Bakteri Yang Berasosiasi Dengan Lalat (Musca domestica). Quagga: Jurnal Pendidikan dan Biologi, 12(1), 11-16. doi: 10.25134/quagga.v12i1.2026.

Received: 28-09-2019

Accepted: 30-12-2019

Published: 20-01-2020

\begin{abstract}
Abstrak: Banyak penyakit yang penyebarannya diperantarai oleh lalat (Musca domestica). Lalat merupakan salah satu vektor mekanis dalam penyebaran penyakit. Saat ini, bakteri resisten antibiotik menjadi masalah serius bagi kesehatan global. Penyebaran bakteri ini salah satunya dapat diperantarai oleh lalat. Hal ini dapat menyebabkan menurunnya kualitas hidup masyarakat sekitar. Tujuan dari penelitian ini adalah untuk menganalisis keberadaan bakteri resisten antibiotik yang berasosiasi dengan lalat dewasa (M. domestica) yang dikumpulkan dari tempat pembuangan sampah di sekitar kampus Universitas Ahmad Dahlan, Banguntapan, Yogyakarta. Tahapan penelitian yang dilakukan yaitu isolasi bakteri yang berasosiasi dengan lalat dewasa kemudian menguji kepekaan bakteri tersebut terhadap antibiotik kanamycin, chloramphenicol, amoxycillin, tetracycline, ciprofloxacin, gentamicin, dan erythromycin. Dari 12 lalat yang ditangkap, bakteri yang diperoleh sebanyak 20 isolat. Persentase resistensi masing-masing isolat terhadap antiobiotik yang diujikan berdasarkan pengukuran zona hambat yang diperoleh yaitu kanamycin 0\%, chloramphenicol 25\%, amoxycillin 25\%, tetracycline 50\%, ciprofloxacin 0\%, gentamicin 0\%, dan erythromycin 75\%. Hasil analisis antibiotik menunjukkan bahwa semua isolat bakteri yang diperoleh telah resisten terhadap satu ataupun dua antibiotik yang diujikan.
\end{abstract}

Kata Kunci: Musca domestica; Resistensi antibiotik; Bakteri.

\begin{abstract}
The housefly, Musca domestica, is insect in close contact with human. It is a vector for various pathogenic bacteria in human. Housfly can carry human pathogens from garbageldump area, hospitals, public parks, animal farms, and domestic habitation. This study examines the antibiotics resistance of bacteria isolated from Musca domestica collected from several garbage dump in Universitas Ahmad Dahlan campus, Banguntapan, Yogyakarta. Isolation of bacteria from external surface of the flies was perfomed using MacConkey Agar (MA). Antimicrobial susceptibility testing was performed using CLSI guideline. There were 7 antibiotics have been used : kanamycin, chloramphenicol, amoxycillin, tetracycline, ciprofloxacin, gentamicin, and erythromycin. A total of 10 houseflies were sampled from different location. Antimicrobial testing showed that all the isolates were resistant to one or two antimicrobial agents that have been used in this study. The present study support the belief that the housefly is important in the spreading of bacterial pathogens and antibiotics resistance.
\end{abstract}

Keywords: Musca domestica; Antibiotics resistance; Bacteria.

\section{PENDAHULUAN}

Lalat (Musca domestica) ditetapkan sebagai vektor mekanis yang paling penting secara medis dalam penyebaran penyakit (WHO, 2006; Scott et al., 2014; Sarwar, 2015). Beberapa bakteri patogen yang berasosiasi dengan lalat telah berhasil diisolasi dari berbagai jenis area, seperti area peternakan, rumah sakit, pasar, tumpukan sampah, restoran dan kantin sekolah. Bakteri patogen banyak yang ditemukan pada permukaan tubuh lalat dewasa maupun pada larva lalat. Beberapa bakteri patogen yang ditemukan berasosiasi dengan lalat yaitu Actinobacter, Aeromonas, Bacillus, Clostridia, Cronobacter, Dipthroid, Enterobacter, Escherichia, Helicobacterium, Klebsiella, Methylobacterium, Morganella, Micrococcus, Proteus, Providencia, 
Pseudomonas, Salmonella, Serratia, Shigella Staphylococcus, dan Streptococcus (Grubel et al., 1997; Banjo et al., 2005; Lamiaa et al., 2007; Vazirianzadeh et al., 2008; Buttler et al., 2010; Fasanella et al., 2010; Gupta et al., 2011; Kassiri et al., 2012).

Saat ini, kesadaran tentang penggunaan antibiotik dengan benar banyak digalakkan. Hal ini dikarenakan banyaknya kemunculan bakteri yang resisten terhadap antibiotik. Resistensi antibiotik adalah keadaan dimana mikroba penyebab penyakit tidak bisa lagi dibunuh dengan menggunakan antibiotik tersebut. Saat ini, informasi resistensi antibiotik di Indonesia masih sangat terbatas. Pada tahun 2015, WHO telah menetapkan Global Awarness on Antimicrobial Resistance (AMR) untuk menanggulangi kasus resistensi antibiotik yang terus meningkat di dunia. Indonesia juga telah menetapkan agenda nasional demi mendukung program WHO tersebut mulai tahun 2017 (Parathon et al., 2017). Penyebaran bakteri resisten antibiotik menjadi masalah serius bagi kesehatan global. Penyebaran bakteri ini salah satunya dapat diperantarai oleh lalat sebagai vektor mekanis penyebaran bakteri patogen. Tujuan dari penelitian ini adalah untuk menganalisis keberadaan bakteri resisten antibiotik yang berasosiasi pada lalat dewasa (M. domestica) yang dikumpulkan dari tempat pembuangan sampah di sekitar kampus 4 Universitas Ahmad Dahlan, Yogyakarta. Kampus 4 Universitas Ahmad Dahlan berlokasi dekat dengan rumah sakit, pasar tradisional, dan pemukiman warga sehingga kemungkinan berpengaruh pada profil bakteri pada lalat yang ada di sekitar kampus.

\section{METODOLOGI PENELITIAN}

\section{Pengambilan Sampel}

Lalat ditangkap secara manual menggunakan jaring pada empat lokasi tempat sampah di sekitar kampus Universitas Ahmad Dahlan, Yogyakarta.

\section{Isolasi Bakteri}

Lalat yang berhasil ditangkap lalu dimasukkan ke dalam $1 \mathrm{~mL} \quad 0.85 \% \mathrm{NaCl}$ kemudian di vorteks. Sebanyak $0,1 \mathrm{~mL}$ sampel diambil kemudian dimasukkan ke dalam medium pertumbuhan MacConkey agar dengan metode spread. Sampel diinkubasi selama 24 jam pada suhu $37^{\circ} \mathrm{C}$. Isolat bakteri yang tumbuh pada medium pertumbuhan kemudian dipindahkan ke medium pertumbuhan baru dengan menggunakan metode goresan 4 kuadran untuk mendapatkan kultur murni. Tiap isolat murni lalu ditumbuhkan pada 2 agar miring pada tabung reaksi, satu kultur disimpan pada suhu $4^{0} \mathrm{C}$ yang digunakan untuk kultur stok sedangkan yang lain digunakan untuk kultur kerja pada suhu $37^{\circ} \mathrm{C}$.

\section{Pewarnaan gram bakteri}

Sebelum dilakukan pengamatan mikroskopis, bakteri harus diwarnai terlebih dahulu dengan menggunakan pewarnaan gram. Isolat tunggal yang telah diperoleh dicuplik dengan menggunakan batang ose kemudian dibuat preparat keringnya. Preparat kering ditetesi dengan kristal violet sebanyak 2-3 tetes dan didiamkan selama 1 menit kemudian dibilas dengan menggunakan air akuades. Setelah kering, preparat ditetesi dengan larutan iodin dan dibiarkan selama 30 detik. Setelah itu, preparat dicuci kembali menggunakan air akuades. Lalu, preparat ditetesi dengan larutan safranin dan dibiarkan selama 20 detik, dibilas kembali dengan air akuades. Preparat bakteri yang telah diwarnai kemudian diamati dibawah mikroskop dengan perbesaran 10x100 kali.

Uji resistensi antibiotik

Uji resistensi antibiotik terhadap isolat bakteri dilakukan dengan menggunakan antibiotik kanamycin, chloramphenicol, amoxycillin, tetracycline, ciprofloxacin, gentamicin, dan erythromycin dengan metode Kirby bauer difusi kertas cakram. Bakteri ditumbuhkan pada medium nutrient agar dengan menggunakan metode spread. Selanjutnya, kertas cakram antibiotik diletakkan di atas permukaan medium yang telah diberi inokulan. Bakteri kemudian diinkubasi selama 14-16 jam dalam suhu ruang. Zona hambat yang telah terbentuk kemudian diukur. Interpretasi data zona hambat disesuaikan dengan standard zona hambat antibiotik dari The Clinical \& Laboratory Standards Institute. 
Quagga: Jurnal Pendidikan dan Biologi

Volume 12, Nomor 1, Januari 2020, pp.11-16
p-ISSN 1907-3089, e-ISSN2651-5869

https://journal.uniku.ac.id/index.php/quagga

\section{HASIL DAN PEMBAHASAN}

Hasil penangkapan lalat di empat lokasi tempat sampah diperoleh total 12 ekor lalat. Lalat yang telah berhasil ditangkap kemudian dibawa ke laboratorium untuk dianalisis lebih lanjut. Dari proses isolasi bakteri, bakteri yang diperoleh berjumlah total 20 isolat. Karakteristik koloni isolat dapat dilihat pada tabel 1.

Analisis resistensi dilakukan menggunakan 7 macam antibiotik yaitu: kanamycin, chloramphenicol, amoxycillin, tetracycline, ciprofloxacin, gentamicin, dan erythromycin. Isolat bakteri yang telah diperoleh kemudian dianalisis ketahanannya terhadap 7 antibiotik tersebut. Antibiotik yang digunakan pada penelitian ini merupakan antibiotik yang umumnya direkomendasikan dalam pengobatan terhadap penyakit infeksi. Hasil uji antibiotik dapat diamati pada gambar 1. Dari ketujuh antibiotik yang digunakan, semua antibiotik merupakan antibiotik dengan spektrum luas kecuali amoxycillin yang memiliki sprektrum sedang.

Zona hambat yang ditandai dengan terbentuknya zona bening disekitar kertas cakram diukur dengan menggunakan jangka sorong. Hasil pengukuran zona hambat kemudian ditabulasikan dan dibandingkan dengan standar pengukuran zona hambat antibiotic dari CLSI. Hasil interpretasi zona hambat dapat dilihat pada tabel 2.

Tabel 1. Karakteristik koloni isolat bakteri

\begin{tabular}{cccccc}
\hline Isolat & Bentuk & Permukaan & Tepi & Warna & Gram \\
& Koloni & Koloni & Koloni & Koloni & \\
\hline L1 & Sirkuler & Convex & Entire & Putih & Negatif \\
L2 & Sirkuler & Convex & Entire & Putih & Negatif \\
L3 & Irregular & Flat & Entire & Putih & Negatif \\
L4 & Sirkuler & Convex & Entire & Putih & Negatif \\
L5 & Sirkuler & Convex & Entire & Putih & Negatif \\
L6 & Irregular & Flat & Entire & Putih & Negatif \\
L7 & Irregular & Flat & Entire & Putih & Negatif \\
L8 & Sirkuler & Convex & Entire & Putih & Negatif \\
L9 & Sirkuler & Convex & Entire & Putih & Negatif \\
L10 & Sirkuler & Convex & Entire & Putih & Negatif \\
L11 & Sirkuler & Convex & Entire & Putih & Negatif \\
L12 & Sirkuler & Convex & Entire & Putih & Negatif \\
L13 & Sirkuler & Convex & Entire & Putih & Negatif \\
L14 & Sirkuler & Convex & Entire & Putih & Negatif \\
L15 & Irregular & Flat & Entire & Putih & Negatif \\
L16 & Sirkuler & Convex & Entire & Putih & Negatif \\
L17 & Sirkuler & Convex & Entire & Putih & Negatif \\
L18 & Sirkuler & Convex & Entire & Putih & Negatif \\
L19 & Sirkuler & Convex & Entire & Putih & Negatif \\
L20 & Irregular & Flat & Entire & Putih & Negatif \\
\hline & & & &
\end{tabular}

Hasil interpretasi menunjukkan bahwa persentase resistensi tertinggi diperoleh pada uji antibiotik erythromycin yaitu sebesar $75 \%$. Antibiotik dengan tingkat resistensi terendah yaitu antibotik kanamycin, ciprofloxacin dan gentamicin yaitu sebesar $0 \%$. Antibiotik dengan tingkat resistensi sedang yaitu pada antibiotic chloramphenicol, amoxicillin dan tetracyclin yaitu masing-masing 25\%, 25\% dan 50\%. Tingkat resistensi yang berbeda dipengaruhi oleh banyak faktor salah satunya yaitu ada atau tidaknya gen pengkode resisten terhadap antibiotik tersebut (Bengtsson et al, 2018)

Antibiotik kanamycin masuk ke dalam golongan antibiotik aminoglikosida. Antibiotik ini merupakan antibiotik spektrum luas dimana efektif membunuh bakteri gram negatif dan beberapa bakteri gram positif. Antibiotik golongan ini bekerja menghambat sistesis protein dengan cara mengikat subunit $30 \mathrm{~S}$ pada ribosom sehingga menyebabkan kesalahan baca kode genetik. Pada umumnya kasus resistensi pada golongan antibiotik ini disebabkan adanya inaktivasi menggunakan enzim.

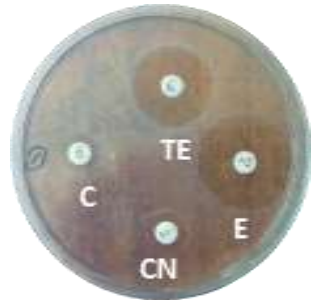

a.

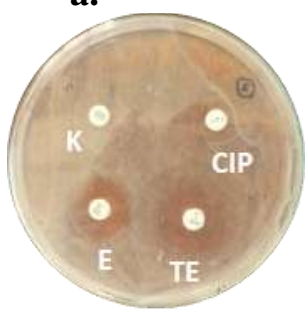

c.

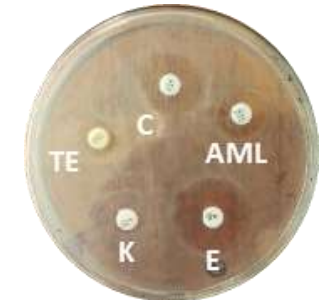

b.

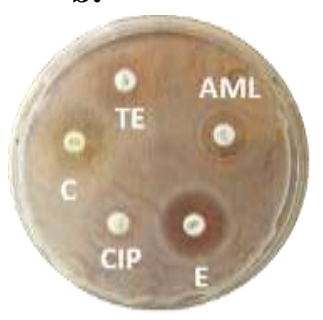

d.
Gambar 1. Uji resistensi antibiotik dengan menggunakan metode Kirby bauer (isolat bakteri a. L1 b. L3 c. L7 dan d. L14) 
Quagga: Jurnal Pendidikan dan Biologi

Volume 12, Nomor 1, Januari 2020, pp.11-16
p-ISSN 1907-3089, e-ISSN2651-5869

https://doi.org/10.25134/quagga.v12i1.2026
Tabel 2. Hasil Interpretasi Zona Hambat

\begin{tabular}{lccccccc}
\hline & K & C & AML & TE & CIP & CN & E \\
\hline L1 & S & S & I & R & S & S & R \\
L2 & S & R & R & S & S & S & R \\
L3 & S & I & I & S & S & S & R \\
L4 & S & S & S & R & S & S & S \\
L5 & S & R & R & S & S & S & R \\
L6 & S & I & I & S & S & S & R \\
L7 & S & S & I & R & S & S & R \\
L8 & S & S & S & R & S & S & S \\
L9 & S & S & S & R & S & S & S \\
L10 & S & S & I & R & S & S & R \\
L11 & S & S & S & R & S & S & S \\
L12 & S & R & R & S & S & S & R \\
L13 & S & R & R & S & S & S & R \\
L14 & S & I & I & S & S & S & R \\
L15 & S & S & I & R & S & S & R \\
L16 & S & S & I & R & S & S & R \\
L17 & S & I & I & S & S & S & R \\
L18 & S & S & S & R & S & S & S \\
L19 & S & R & R & S & S & S & R \\
L20 & S & I & I & S & S & S & R \\
\hline Persentase (\%) & 0 & 25 & $\mathbf{2 5}$ & $\mathbf{5 0}$ & $\mathbf{0}$ & $\mathbf{0}$ & $\mathbf{7 5}$ \\
\hline
\end{tabular}

Keterangan :

Antibiotik K : Kanamycin (30 $\mu \mathrm{g}), \mathrm{C}$ : Chloramphenicol $(30 \mu \mathrm{g})$, AML : Amoxicillin $(25 \mu \mathrm{g})$, TE : Tetracycline $(30 \mu \mathrm{g})$, CIP : Ciprofloxacin $(30 \mu \mathrm{g}), \mathrm{CN}$ : Gentamicin (30 $\mu \mathrm{g}), \mathrm{E}$ : Erythromycin $(30 \mu \mathrm{g})$.

$\mathrm{S}$ : Susceptible; I : Intermediet; R : Resistant Interpretasi data zona hambat disesuaikan dengan standard zona hambat antibiotik dari The Clinical \& Laboratory Standards Institute

Bakteri yang resisten terhadap kanamycin memiliki enzim untuk menginaktivasi aminoglikosida dengan cara memodifikasinya (Tsodikova, 2016). Antibiotik gentamycin merupakan antibiotik aminoglikosida, sama dengan antibiotik kanamycin. Pada penelitian ini, tidak ditemukan adanya resistensi isolat bakteri terhadap antibiotik kanamycin maupun gentamicin.

Antibiotik chloramphenicol merupakan antibiotik dengan spektrum luas karena memiliki efek bakteriosidal terhadap bakteri gram positif maupun negatif. Antibiotik ini bekerja dengan cara mengikat protein subunit 50S pada ribosom bakteri sehingga dapat menghambat proses sintesis protein. Antibiotik ini dapat dipakai untuk pengobatan penyakit kolera, tipus dan lain-lain. Resistensi terhadap antibiotik ini dapat disebabkan oleh teraktivasinya enzim detoksifikasi yaitu chloramphenicol acetyltransferase (CAT) (Schwarz et al., 2004). Pada penelitian ini ditemukan 5 isolat telah resisten terhadap antibiotik chloramphenicol dengan persentase resistensi sebesar $25 \%$.

Antibiotik amoxicillin merupakan golongan antibiotik beta-laktam. Mekaniskme kerja antibiotik ini yaitu merusak dinding sel bakteri. Antibiotik ini merupakan antibiotik dengan spektrum moderat yaitu efektif dalam membunuh bakteri gram positif dan beberapa bakteri gram negatif diantaranya Hemophilus influenza, E.coli, Proteus mirabilis, Salmonella sp., dan Shigella sp. (Werth., 2018).

Antibiotik tetracycline merupakan antibiotik dengan spektrum yang luas. Mekanisme kerja dari antibiotik ini yaitu mengikat protein subunit $30 \mathrm{~S}$ pada ribosom sehingga menyebabkan protein sintesis terhambat. Resistensi terhadap antibiotik ini dapat disebabkan oleh beberapa mekanisme diantaranya yaitu keberadaan pompa tetracycline, ribosom bakteri terikat pada suatu protein sitoplasmik sehingga sisi pengikatan tetracycline akan terlindungi, modifikasi tetracycline, atau modifikasi 16S rRNA pada sisi pengikatan tetracycline. Berjalannya proses resistensi ini dibantu oleh lebih dari 20 grup protein di dalam sel bakteri (Li et al., 2013).

Antibiotik ciprofloxacin merupakan antibiotik golongan quinolone. Kinerja antibiotik ini adalah dengan cara menghambat kerja enzim topoisomerase II (DNA gyrase) dan topoisomerase IV yang berperan penting dalam sel bakteri pada proses DNA replikasi, transkripsi, dan lain-lain. Resistensi pada antibiotik ini disebabkan oleh beberapa faktor seperti peningkatan pompa efflux, enzim modifikasi dan protein pelindung target. Selain itu, penelitian menunjukkan bahwa mekanisme resistensi ini bersifat tergantung pada spesies bakterinya (Redgrave et al., 2014). 
Quagga: Jurnal Pendidikan dan Biologi

Volume 12, Nomor 1, Januari 2020, pp.11-16
p-ISSN 1907-3089, e-ISSN2651-5869

https://journal.uniku.ac.id/index.php/quagga
Antibiotik erythromycin merupakan antibiotik golongan makrolid. Antibiotik ini memiliki spektrum luas dimana bakteri ini bekerja dengan cara mengikat subunit 50S ribosom bakteri. Penggunaan antibiotik ini salah satunya adalah untuk pengobatan infeksi kulit. Resistensi terhadap antibiotik ini banyak terjadi pada Streptococci, salah satunya bakteri Streptococcus pyogenes. Selain itu, telah ada laporan resistensi antibiotik ini pada bakteri Streptococcus pneumonia. Mekanisme resistensi pada antibiotik ini dapat disebabkan oleh adanya pompa erythromycin atau adanya metilasi pada 23S ribosom pada bakteri (Wasko et al., 2012).

Dari hasil pengamatan yang telah dilakukan, dapat disimpulkan bahwa hampir semua isolat yang dianalisis pada penelitian ini resisten terhadap lebih dari satu macam antibiotik. Keadaan ini biasa dikenal dengan istilah Multi-Drug Resistant (MDR). Kasus MDR tentu saja sangat merugikan. Jika seseorang menderita penyakit infeksius yang disebabkan oleh bakteri MDR, pengobatan yang dilakukan akan lebih sulit. Hal ini dikarenakan opsi pengobatan dengan menggunakan antibiotik menjadi terbatas dan seringkali harus menggunakan antibiotik dengan resiko efek samping yang lebih tinggi.

Menurut Zhang et al., (2018), lalat berpotensi dijadikan sebagai indikator penyebaran bakteri resisten antibiotik. Lalat dapat masuk ke banyak area ekosistem dan sangat dekat dengan kegiatan manusia. Penggunaan indikator ini lebih praktis dibandingkan analisis menggunakan sampel dari manusia dan hewan ternak yang seringkali memerlukan pemeriksaan dengan biaya yang cukup mahal dan lama.

\section{SIMPULAN}

Pada penelitian ini berhasil ditangkap 12 lalat dan diisolasi sebanyak 20 isolat bakteri. Persentase resistensi masing-masing isolat terhadap antiobiotik yaitu kanamycin $0 \%$, chloramphenicol 25\%, amoxycillin 25\%, tetracycline $50 \%$, ciprofloxacin $0 \%$, gentamicin $0 \%$, dan erythromycin $75 \%$.

\section{REFERENSI}

Banjo, A.D, O.A. Lawal, \& O.O. Adeduji. (2005). Bacteria and fungi isolated from housefly (Musca domestica L.) larvae. African Journal of Biotechnology, 4(8): 780-784.

Bengtsson-Palme, Johan., Erik Kristiansson, dan D.G. Joakim Larsson. (2018). Environmental factors influencing the development and spread of antibiotic resistance. FEMS Microbiology Reviews, 42(1):68-80.

Buttler, J.F., A. Garcia-Maruniak, F. Meek, \& J.E. Maruniak. (2010). Wild Florida house flies (Musca domestica) as carriers of pathogen bacteria. Florida Entomologist, 93(2): 218-223.

Fasanella, A., S. Scasciamacchia, G. Garafolo, A. Giangaspero, E. Tarsitano, \& R. Adone. (2010). Evaluation of the house fly Musca domestica as a mechanical vector for an anthrax. Plos One, 5(8): $1-5$.

Grubel, P., J.S. Hoffman, F.K. Chong, N.A. Burstein, C. Mepani, \& D.R. Cave. (1997). Vector potential of houseflies (Musca domestica) for Helicobacter pylori. Journal of Clinical Microbiology, 35(6): 1300-1303.

Gupta, A.K., D. Nayduch, P. Verma, B. Shah, H.V. Ghate, M.S. Patole, \& Y.S. Shouce. (2011). Phylogenetic characterization of bacteria in the gut of house flies (Musca domestica L.) FEMS Microbiol. Ecol., 79: 581-593.

Kassiri, H., K. Akbarzadeh, \& A. Ghaderi. (2012). Isolation of pathogenic bacteria on the house fly, Musca domestica L. (Diptera: Muscidae), body surface in Ahwaz hospitals, Southwestern Iran. Asian Pacific Journal of Tropical Biomedicine, 673-678.

Lamiaa, B., L. Mariam, \& A. Ahmed. (2007). Bacteriological analysis of Periplaneta americana L. (Dictyoptera: Blattidae) and Musca domestica L. (Diptera: Muscidae) in ten district of Tangier, Marocco. African Journal of Biotechnology. 6(17): 2038-2042. 
Li, W., Gemma C. Atkinson, Nehal S. Thakor, Ular Allas, Chuao-chao Lu, Kwok-Yan Chan, Tanel Tenson, Klaus Schulten, Kevin S. Wilson, Vasili Hauryliuk \& Joachim Frank. (2013). Mechanism of Tetracycline Resistance by Ribosomal Protection Praotein Tet(O). Nat Commun. 4:1477.

Parathon, Harry., Kuntaman., Tri H. W., Bayu T. M., Anis K., Mariyatul Q., Zunilda D., Jihane F.T., Tjandra A., Visanu T., \& Sirenda V. (2017). Progress toward antimicrobial resistance containment and control in Indonesia. BMJ, 358: j3808.

Redgrave, Liam S., Sam, B.S., Mark A. W., \& Laura J.V.P. (2014). Fluoroquinolone resistance : mechanisms, impact on bacteria, and role in evolutionary success. Trends in Microbiology. 22(8) : 438-445.

Schwarz S, Kehrenberg C, Doublet B, \& Cloeckaert A. (2004). Molecular basis of bacterial resistance to chloramphenicol and florfenicol. FEMS Microbiol Rev. 28(5) : 519-42.

Tsodikova, Sylvie \& Kristin J. Labby. (2016). Mechanisms of Resistance to Aminoglycoside Antibiotics : Overview and Perspective. MedChemComm. 7(1) : 11-27.

Vazirianzadeh, B., S.S. Solary, M. Rahdar, R. Hajhossien, \& M. Mehdinejad, (2008). Identification of bacteria which possible transmitted by Musca domestica (Diptera: Muscidae) in the region of Ahvaz, SE Iran. Jundishapur Journal of Microbiology, 1(1): 28-31.

Wasko, Adam, Katarzyna Skrzypczak, Magdalena Polak-Berecka \& Adam Kuzdralinski. (2012). Genetic mechanisms of variation in erythromycin resistance in Lactobacillus rhamnosus strains. The Journal of Antibiotics, 65, 583-586.

Werth, Brian. (2018). Penicillin. MSD Manual Professional Version. (Online), (http://www.msdmanuals.com), diakses 12 Agustus 2019.
Zhang, J., Jiawei W., Li Chen., Afrah K.Y., Patrick K., Patrick B., Jing Li., Jiansen G., Russel C., Kezong Q. \& Chengming W. (2018). Housefly (Musca domestica) and Blow Fly (Protophormia terraenovae) as vectors of bacteria carriying colistin resistance genes. Applied and Environmental Microbiology. 84(1): e01736-17. 